\title{
ISLAM, DEMOCRACY, AND THE ROAD TO MODERATION: TESTING THE POLITICAL COMMITMENT OF INDONESIAN MUSLIM ACTIVISTS
}

\author{
Jamhari Makruf*
}

\begin{abstract}
The emergence of 'radical Islamist' movements has challenged the characteristics of Indonesian Islam, which is traditionally moderate and tolerant. According to the author, 'Islamic radicalism' is not a new force in Indonesian politics. However, never before have associations espousing such an ideology reached the current level of support. In light of this situation, this article tries to examine the political commitment of 'Islamist' political movements in the context of Indonesia's current democratising process.
\end{abstract}

\section{Introduction}

Nearly a decade of political transition to democracy in Indonesia has led to striking phenomena for political movements organised on the basis of Islam.

On the one hand, the 'Islamist' political movements that transformed themselves into parties and participated in electoral politics are now moving toward pragmatic and moderate political orientations. Leaders in 'Islamist' political parties - political groups who hold a set of ideologies derived from the doctrine that Islam is not only a religion, but also a political system that governs the legal, economic and social imperatives of the state - moderated their agendas in order to exploit the democratic institutions for political competition. Recent trends in the ideological positions of Muslim-based political parties in the two national elections of 2004 and 2009 revealed that democratic institutions have disciplined the elite of the parties to abandon the agenda for the establishment of an Islamic state of Indonesia in favour of the strategic incentives of winning elections.

On the other hand, the 'radical' 'Islamist' social movements have eventually come to challenge the very foundation of the secular state of Indonesia. From the end of the 1990s to the mid-2000s, 'radical' 'Islamist' movements have demonstrated

* Jamhari Makruf is the Vice-Rector of Academic Affairs, State Islamic University (UIN Syarif Hidayatullah), Jakarta, Indonesia. 
force in their struggle to apply Islamic shari ${ }^{-} a h$ law in Indonesia. In many cases, these movements use street-demonstrations, civic protests, social-economic services and public discourse - including religious fatwa $\bar{a}$ - to express their religiopolitical interests.

\section{Islamic Moderation and the Indonesian Case}

This article seeks to explain the emergence of a moderate and pragmatic political orientation of Muslim political parties in democratising Indonesia. By political moderation of 'Islamists', I refer broadly to the stated positions of 'Islamist' leaders and groups concerning their commitment to national constitution, democracy and the equal rights of citizenry. Political moderation also includes changes in the stated views of political movements or civic associations relative to their ideological position in the past. I will argue that the force that seems to have driven these two different logics of 'moderation' and 'radicalisation' is the interaction between the institutional design of the nation-states and the considerable expansion of opportunities for change - in particular political crises. That is to say, the challenge of democratic regimes and of the nation-state were both abrupt and long in the making, and both sets of events spoke to the institutions of the regimes in power even as these regimes were in crisis. Elections, as one of the most important institutions guaranteeing the political legitimacy of ruling regimes in nation-states, serve as a window that may be used by the elite to uphold political mobilisation defined within the framework of the nation's religious markers.

Scholars of political Islam have explored the moderation and 'radicalisation' of 'Islamism' by emphasising the role of culture. There are two camps of cultural analysis. The first are those scholars who challenge the thesis of moderate Islam. They posit that 'Islamism' is rooted in the Islamic scriptures and classics and shaped by Muslim political experiences ${ }^{1}$ and, accordingly, moderation in political Islam does not exist. Daniel Pipes, for example, argues that Islamic identities are deeply rooted effective ties that shape primary loyalties and affinities. While not assuming that all Islamic texts and traditions lead to a certain politicised action, certain scholars believe that Muslims possess a strong sense of religio-cultural identity that is the primary shaper of their actions and worldview. ${ }^{2}$

The second camp is composed of scholars who argue the opposite. To John Esposito, Graham Fuller and Charles Kurzman, just to name a few, 'Islamist' political movements change over time. Some movements publicly endorsed democratic representation, pluralism, and human rights. These scholars also depict a character of political Islam which is neither essential, primordial, nor constant. In fact, many Islamic thinkers have offered interpretations qualifying or even rejecting the concept of the inseparability of the political and religious domains. ${ }^{3}$ The classical 
Islamic texts and traditions also reveal that there are elements that could assist the development of democratic ideas and practices. ${ }^{4}$

My observations on political Islam in contemporary Indonesia offer a different analytical framework to explain how political movements that share similar political ideas and cultural worldviews pursue different logics of political contestation. 'Islamist' political movements that have decided to involve themselves in parliamentary politics moderate their agendas as a strategic adaptation to changes in their political environment. The instalment of democratic institutions after the collapse of the New Order in 1999 helped a number of 'Islamist' parties re-emerge. Yet, the ways in which these 'Islamist' parties uphold their mobilisation strategies differ significantly from the past. Two main features bear testimony to this difference. The first is the absence of Islamic state alternatives during political campaigns in the 1999 and the 2004 elections; and, the second is the relatively inclusive political platforms of Muslim political parties in qualifying their strategic behaviour in Indonesia's political process today.

Almost all of political parties relying on Muslim voters claim that their political aspiration is inclusive and plural. The PKB (an NU-affiliated political party), for example, which controlled 57 seats (11\%) in the 1999 election, recruited a broad range of political leaders including a number of nationalists - mostly from NGO activists and modernist Muslims. The PAN (a Muhammadiyah-affiliated party) built a coalition with two small Islamic parties, the PBB and PK, and together they controlled 49 seats (7\%); PAN also proclaimed itself to be an inclusive Muslim party. The PPP, an Islamic party that frequently mobilised its constituency for the implementation of Islamic law, abandoned its long-standing platform supporting the Jakarta Charter during the parliamentary session for constitutional amendments in 1999 and 2000.

The same logic of electoral behaviour continued in the 2004 presidential elections. The PBB, a proto- 'Islamist' political party descended from the vanguard 'Islamist' party after independence, Masyumi, forged a political coalition with a nationalist party, PD - later with PKS, PKB and PAN - to support Susilo Bambang Yudoyono in the presidential race. Meanwhile, PPP became a vote-getter for Muslim masses in the National Coalition led by PDI-P and Golkar (both secular-nationalist parties) and PDS (a Christian-oriented party), to support Megawati Sukarnoputri in the presidential election.

The two subsequent democratic elections in Indonesia illustrated how the democratic political system presented the 'Islamists' with a choice: commit themselves to an Islamic state agenda for the establishment of a moral community based on the sharì 'ah, or to work through political institutions. Some 'Islamist' leaders, of course, decided to participate in elections because this democratic institution enabled them to pursue their Islamic state agenda in parliament (if 
they won) and to legislate Islamic ideals for Indonesian society. A majority of 'Islamist' leaders, however, expected that by entering into democratic elections their constituents would be represented in the political decision-making process. Although Muslim political parties fared poorly in the elections of 1999, 2004 and 2009 , their leaders were eventually able to gain new access to the process of political decision-making.

While elections offered the Indonesian 'Islamists' a new route to power, democratic institutions also subjected them to certain constraints. Participation in electoral games has made the leaders of Muslim parties realise that any attempt to replace the current national constitution with an Islamic alternative would provoke a far-reaching political crisis that would deprive them of popular support. Furthermore, by maintaining moderate positions in dealing with the issue of Islamic-constitutional amendment, the Muslim-based political parties undoubtedly secured the newly-created democratic institutions against a return to politics by the military (notwithstanding former army men who have participated as civilians, like the current president). Whatever their political commitments reveal, this move towards pragmatism by political Islam establishes a new principle for 'Islamist' parties in a democracy: there is no single ideological formulation embraced within 'Islamist' parliamentary politics. For Indonesian 'Islamist' political parties, thus, political moderation is taken in order to enhance their credibility with the Indonesian electorate or to secure cooperation and alignment with other political groups, especially from secular-nationalists.

Such a political moderation is not new. From a comparative standpoint, observing the phenomenon of social democracy in Western Europe, Adam Przeworski ${ }^{5}$ notes that the establishment of democratic political systems in Europe based on universal adult suffrage presented the left political movements with a dilemma: to pursue socialist revolution through direct confrontation in the workplace or to struggle for the establishment of socialist ideals through parliamentary politics. It eventually became clear that the decision to participate in elections brought with it the political consequence of moderating the revolutionary ideologies and agendas. Transition to state socialism has never been pursued through parliament, because any attempt to dismember the political-economic structure of capitalism would provoke a far-reaching economic crisis. Electoral pressure thus forced 'radical' leftist political movements to abandon their ultimate goal of democratic transition to socialism.

However, political moderation of 'Islamist' political parties is not automatically spread to other 'Islamist' movements, many of which continue to pursue an Islamic alternative through civic association networks. In other words, the enduring 'radical' ideological position of certain 'Islamist' movements demonstrates that participation does not inevitably induce political moderation. No single-issue structure is exhibited in their political goal and agenda. But the population was mobilised 
by such organisations around Islamic symbols, threats from secularism and other religions, and opposition to Western/American economic imperialism. Urban and educated communities were linked together and glorified as the main thrust of 'Islamisation' for the nation.

Observers of Indonesian politics have noted that the mobilisation capacity of the Islamic social movements, while perhaps still falling short of its peak in the $1950 \mathrm{~s}$, had, by the early 2000s, produced one of the most formidable political forces in Indonesia. A 'radical' group such as the Lasykar Jihad was estimated to have 2 to 3 million members within its cells - known in Indonesian as 'brothers' (ikhwan) - in Indonesian districts, urban mosques, campuses and the villages outside the island of Java. ${ }^{6}$ This particular 'Islamist' movement is the main actor in the struggle for an 'Islamic state of Indonesia', with its own Islamic-oriented guerrilla group sent to regions of conflict across the country. The circulation of Lasykar's organ, Sabily ('My Path'), reached between 500,000 and a million. The Front Pembela Islam (FPI, or 'Islamic Defence Front'), operating in urban areas, commanded around 1 million members and the allegiance of one-fifth to one-third of the student body, allowing them to dominate student unions. ${ }^{7}$ Hizbut Tahrir (Liberation Party) organised 100,000 members centred on campuses and youth organisations. ${ }^{8}$

The most prominent and long-standing 'Islamist' movement is Dewan Dakwah Islamiyah (DDI, or 'Islamic Preaching Council'), a Jakarta-based national private organisation, founded in 1967. This organisation is associated with former Masyumipoliticians who favoured the establishment of an Islamic state through religious mobilisation in media, preaching activities and social networks. Although the organised strength of the 'Islamist' organisations concentrated on campuses and other urban centres, their appeal spilled over into the general populace of the city, rural towns and even villages, where leaders organised around mosques and religious schools. In some places the movement developed its own clinics, cooperatives, and small industries. ${ }^{9}$ DDI's intellectuals and preachers have been engaged in continued debate about the relationship between religion and the state with secular-nationalist leaders, including moderate-modernist Muslim thinkers. Liddle regards this group as a scripturalist Islamic movement, as its main intellectual position within the debate was committed to the implementation of the shari ${ }^{\prime} a h$. Interestingly, during Suharto's political accommodation through ICMI, DDI became one of the main proponents of Suharto's Islamic policies, claiming that there was no longer a significant group of Indonesian Muslims who favoured an Islamic state - as the term used in the $1950 \mathrm{~s}$ - yet asserting that a new political Islam would be like the Christian democratic parties of Europe. ${ }^{10}$

In contrast to 'Islamist' political parties, one important feature of these 'Islamist' social networks is that they are built on an educational background, which is generally linked to Middle Eastern learning centres, in particular Saudi Arabia, 
Egypt, and Pakistan. Historically speaking, networks among Muslim traders and Sufis in the Malay-Indonesian archipelago were instrumental in the spread of Islam. ${ }^{11}$ During Dutch colonial times, 'ulamā' who returned from the Muslim learning centres of the Arabian Peninsula developed intellectual networks responsible for the rise of Islamic reformism and the establishment of Muslim learning institutions, oriented toward the purification and intellectualisation of Islam. ${ }^{12}$ It is just such an educational-religious network that dominates the features of 'Islamist' movements in current Indonesian politics: linked to graduates from Middle Eastern schools, oriented to shari 'ah-minded thinking in religious outlook, with a preferred agenda for the establishment of an Islamic state through the 'Islamisation' of society.

\section{Testing the Political Commitment of Islamic Political Parties}

Typical of a country with cultural and religious diversity, Indonesia has had a long debate about state ideology throughout its history. Indonesia finally reached a consensus - after a bitter debate - around one single ideology, the Pancasila, a stateideology that comprises various factions, but also a blend of different ideological orientations. The first pillar reflects religious outlook, emphasising the belief in the oneness of God, the second pillar reflects on universal humanity, the third has faith in the unity of Indonesia, the fourth applies the democratic principle of people's deliberation, and the last pillar observes socialism. Even if it was a compromise, challenges to its legitimacy have been recurring over time, in which the most well-known threats came from 'Islamists' and Communists. While the Communist scare has been virtually eliminated from this country following the abortive coup of 1965, opposition by 'Islamists' to Pancasila appears imminent. It was the 'Islamists' who confronted the secular faction in the early years of independence, and it was also this group that rebelled against the Old Order government.

The rise of the New Order military regime in the late 1960s succeeded in narrowing the opportunity for any group, including the 'Islamists', to oppose the state system and its concomitant ideology. The authoritarian regime of the New Order ended the vibrant yet anarchic political rivalries of the Old Order period. Nonetheless, the hardest opposition power this regime had to confront in the course of its power came from the 'Islamists'. When the New Order attempted to unify the ideological basis of political and social organisations in the mid-1980s, several Muslim organisations strived to defend their Islamic ideology. Some Muslim factions even engaged in violent clashes with authority, which heightened the tension between the government and Muslim groups in general. Throughout the 32 years of its power, the New Order's relationship with Muslim organisations was always uneasy, caught up in distrust and suspicion. The regime was relatively successful in suppressing the political aspirations of the 'Islamists', forcing them to shift 
their religious orientations to more social and spiritual in character. Clandestine movements occurred sporadically, but the strength of the state networks limited such movement such that it could not grow into a national phenomenon.

Following the collapse of the repressive New Order in 1998, many new political parties were established. Several of these overtly proclaimed Islam as their ideological platform, undermining the long-established provision that the sole ideological basis of political and social organisations had to be Pancasila. This trend was not only shown by the newly created parties such as the PBB ('Crescent and Moon Party') and PKS ('Justice and Prosperity Party'), but also by the old PPP ('Unity and Development Party'). It appears that Suharto's authoritarianism did not succeed in domesticating the 'Islamist' groups, but merely made them dormant. The political openness brought by democratisation following Suharto's fall awakened the memories of some Muslim factions to revive the struggle for an Islamic state and society. However, people's response to the emergence of 'Islamist' groups in national politics varied. Mostly, the people viewed these groups as an unavoidable consequence of democratisation. The secular groups did not express too much worry about the revival of 'Islamist' politics. Moreover, the two influential Muslim groups, the NU and Muhammadiyah, continued to maintain their political moderation. These organisations preferred to create nationalist rather than religious parties, opening the opportunity for even non-Muslim politicians to join. Although NU and Muhammadiyah did not officially stand behind the establishment of PKB and PAN, respectively, prominent members of these two organisations initiated the parties.

As widely predicted, secular parties dominated the first democratic general election in 1999, during which the 'Islamist' parties suffered serious defeats. Supporters of Islamic parties argued that the defeat of Islamic parties was because of the friction between these parties themselves. However, even if the number of voters of all Islamic parties were united into one party, the number would still be outnumbered by the secular nationalist parties' returns. It seems that the defeat of Islamic political parties was because they sold an old agenda, the 'Islamist' agenda, which had already failed in the past. When PKS in 2004 disregarded the 'Islamist' agenda and promoted a more general agenda, especially opposition to corruption, the PKS gained more votes. This is a reason why Islamic political parties have to embrace moderation in their political agenda.

The dataset on the condition of Indonesian nationalism offers some empirical findings that can be used to explain the Islamic political parties. The information of this data is based on a national survey that was conducted in early 2007 by the Centre for the Study of Islam and Society of the State Islamic University (PPIM-UIN). There was a serious question of whether democracy in Indonesia was only producing Islamic parties that would sooner or later facilitate the establishment of an Islamic state in Indonesia. Of course, it is true that democracy in Indonesia will not work 
without the support of Indonesian Muslims, as they are the majority. The PPIM survey was conducted to gauge the level of Muslims' commitment to nationalism.

The survey first questioned respondents about the most important aspect of their personal identity. About 44\% answered that they are Indonesian (orang Indonesia), whereas $43 \%$ of them said they are Muslims (orang Islam). Only 11\% said that they are part of local community (orang daerah). See Figure 1.

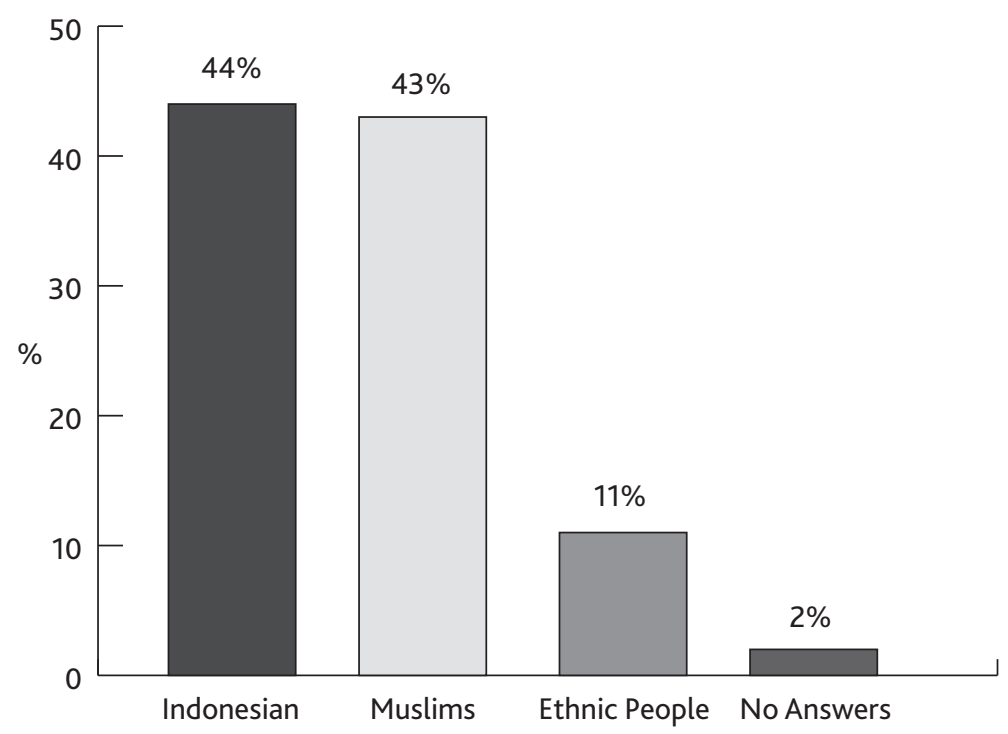

Figure 1 Self-identification in Indonesia (2004)

The results of this survey indicated that Islam and Indonesia are both very important aspects of identity for Indonesian Muslims, yet we cannot be certain that this proclivity would automatically corrode the spirit of nationalism. As a matter of fact, people's identity is always multi-layered, and the relationship between each identity is not always contradictory. In direct contradiction to Huntington's famous theory of the 'Clash of Civilisations', one may identify her/himself as Muslim while at the same time as Indonesian and Javanese. The order may differ, but each identity should not be understood as always incompatible with each other. Huntington ${ }^{13}$ rightly insists that religion and ethnicity are exclusionary identities, for which nobody could be Muslim and Christian or Javanese and Sumatrans at the same time. However, this does not mean that such an exclusionary identity could not stand in combination with another aspect of identity, for it would cease being exclusive if it meets a different category of identity, such as in the case of Muslim and Sumatran. 


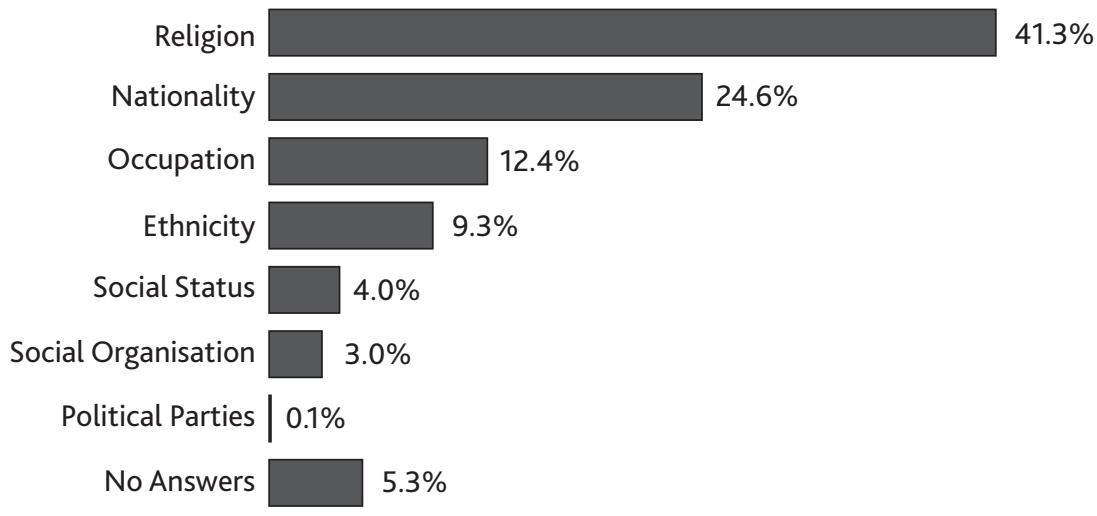

Figure 2 The first most important factor in identifying self-identity (2004)

The data shows that being Muslim is not necessarily abandoning other identities. When asked the second most important personal identity, the majority still point to this religion (29.3\%) and ethnic background ranks second (17.6\%). Interestingly, a further question as to which identity is the third most important, most respondents (20\%) prefer Indonesia, while ethnic background comes third (19\%) after occupation, and religion (10.9\%) accounts for fifth after social status. Owing to the interchangeable usage of these identities, we cannot conclude that the emergence of the 'Islamist' power has altered the long-established pattern of common identity among Indonesian Muslims. There is a strong tendency among these people to adopt the three identities altogether as their defining personal characters.

This non-contradictory relationship of Islamic and Indonesian identity has been further indicated in the respondents' attitude towards the state ideology and constitution. The overwhelming majority of them (91.6\%) endorse Pancasila and the 1945 Constitution as the national political ideology and the state constitution. Those who agree with a blanket statement that the state ideology is Pancasila and not Islam account for $84.7 \%$, meaning Muslims' support of Pancasila is beyond question. For that reason, $90.4 \%$ of the respondents feel it necessary to adjust Islamic law to the framework of national ideology and the constitution. Nevertheless, as has been indicated earlier, $22.8 \%$ of respondents support the idea of erecting an Islamic state. In addition, the implementation of Islamic law, such as the punishment of cutting off the hand, also receives substantial support (26.2\%). Surely, one cannot neglect these phenomena, even if we cannot have a conclusive argument that the state ideology is in danger. For one thing, the existence of the 'Islamist' faction in Indonesia is a fact, not fiction, such as is empirically indicated in the support for an Islamic state and law. However, there is an overlap in support for Pancasila and the 1945 Constitution (91.6\%) and support for an Islamic state (22.8\%), implying that some supporters 
of Pancasila also aspire to have Islam as part of the national ideology. This could be a small number of groups which are seeking to have Pancasila 'Islamised'.

Given that Pancasila, the 1945 Constitution, and national identity have a firm grip on Muslims' socio-political visions, it seems unlikely that the 'Islamist' faction will be able to change Indonesia's political foundations in the foreseeable future. This movement would need enormous support and investments in order to change the people's fundamental beliefs about who they are and which direction their society should be headed. Still, if they were able to secure that financial support, some findings have given strong indications about the opportunities that the 'Islamists' could harness to advance their agenda. People's trust in Muslim religious leaders is higher than in the state bureaucrats, and religious tolerance among Muslims is relatively weak. Theoretically, the 'Islamists' could ride on this trend to further disseminate their messages throughout the country. A closer look at these trends among Muslims, however, reveals that the opportunity for the 'Islamists' to capitalise on the people's dissatisfaction with the government is only partially available.

The trust in the 'ulama ' is as high as ever. According to the PPIM-UIN survey in 2001, 2002, 2004, and 2007, the 'ulama' ' always rank the top above any leaders in winning the heart of Muslims. Interestingly, trust in the 'ulamā' also experiences fluctuation, where in the course of 2001-04 only about $25 \%$ of respondents gave their recognition to religious leadership. This number underwent a steep increase from 2004 onward, and in 2007 reached a record of more than 40\%. Even though less popular, the president and armed forces also experienced the same trend, gaining more support especially after 2004. Unfortunately, support for politicians in the People's Representative Council and in political parties has not increased; they remain the least trustworthy leaders in the eyes of Indonesians. At this point, the popularity of religious leaders is likely correlated with the growing discontent towards public institutions in general that has been generated by the political transition in the early years of democratisation. In other words, given that the president and armed forces have also undergone the same fluctuation, the high popularity of the 'ulama' ' does not necessarily indicate the rise of the 'Islamist' groups. This conclusion is also supported by the fact that the majority of the 'ulama ' in the influential Muslim organisations are not 'Islamists', in the sense that they hold a more moderate political vision.

Discontent towards the government's performance is quite serious, not only as pertains to its minimum capacity but also to the demand for fundamental reforms. Most people at the grassroots level do not turn to the government when they meet difficulties, but to other social institutions outside the state to ask for help. For instance, if they become victims of crime, they prefer to go to a local leader (45\%) or family and neighbours (31.5\%) rather than to the police (16.8\%). Likewise, they prefer to go to neighbours (44.6\%) and local leaders (35.3\%) to ask for assistance if 
they have economic hardship but not to the Office of Social Affairs (10.9\%). This tendency may partly explain the reason why religious leaders are more popular than the state officers, as their presence in society is more salient. The gap between the state and society is also apparent in the people's demand for the transfer of more power from central to local government. When asked their preferences regarding the state administrative system, $53.9 \%$ of respondents prefer to have power balanced between local and central government, and only $22.8 \%$ choose to maintain a more centralised government. Interestingly, those who aspired to have a federal system constitute only $8.3 \%$ of respondents, and those who agree with granting independence to the provinces that wish to obtain it are less than $1 \%$. At this point we could infer that, even though many people feel dissatisfied with the government, such a feeling does not likely lead to the withdrawal of support for the Indonesian nation-state. It would be a rushed conclusion to say that current social unrest and economic dissatisfaction would inevitably lead to the break-up of this country.

\section{Conclusion and Recommendations}

Islam in Indonesia will always be a political issue. Not only do Muslims constitute $87 \%$ of the Indonesian population, but Islam is also still a form of political capital and political identity.

By taking all of these trends into account, does it all mean that the 'Islamists' can never gain power? The answer is affirmative for at least the foreseeable future. This is the reason behind the weakening of Indonesian support toward 'Islamist' groups. Some 'radical' 'Islamist' groups, such as Lasykar Jihad, have had to close themselves down, as Indonesian Muslims showed their disagreement with their ideology and activities. Moreover, the performance of Islamic-based political parties in the Indonesian general election in 2004 and 2009 were showing trends of decreasing support. While social identity as a Muslim is quite strong, it does not transform into political support for Islamic political parties.

- In closing, it seems that moderation in the platform and activities of political parties has become a prerequisite to gain support from Indonesian Muslims. This is the exact reason why the PKS changed its platform and agenda from being a more 'Islamist' agenda to focusing on social services and clean performance of its politicians. This party has created a social platform on health care, education, and sound leadership.

- 'Islamist' social movements have to take into account the diversity of Indonesian Muslims.

- Though we could see the revival of 'Islamist' group in Indonesia over time, it will not be prolonged unless 'Islamist' groups moderate their ideological platforms.

ICR 2.3 Produced and distributed by Pluto Journals ICR.plutojournals.org 


\section{Notes}

1. Bernard Lewis, The Roots of Muslim Rage (Chicago: Chicago University Press, 1988), 16-67; Martin Kramer, "Fundamentalist Islam at Large: The Drive for Power", Middle East Quarterly (June 1996), 37-79; Emmanuel Sivan, Radical Islam: Between Medieval Islam and Modern Politics (Oxford: Oxford University Press, 1991).

2. Bernard Lewis, The Political Language of Islam (Chicago: Chicago University Press, 1990); Sivan, Radical Islam. Kramer, for instance, pointed out that Muslim individuals and communities commonly react to and/or defend divinely-derived concerns, particularly when they perceive a disadvantage or long-standing abuse at the hands of anti-Islamic or secular institutions. The emergence of 'Islamist' political phenomena are therefore perceived as a natural manifestation of integral Islamic injunctions and identities; see Kramer, "Fundamentalist Islam", 37-71.

3. Leonard Binder, Islamic Liberalism (Chicago: Chicago University Press, 1984); Charles Kurzman, Liberal Islam: A Source Book (Oxford: Oxford University Press, 2000).

4. Dale F. Eickelman and John O. Voll, Muslim Politics (Princeton: Princeton University Press, 1997).

5. Adam Przeworski, Social Democracy in Historical Perspective (Cambridge: Cambridge University Press, 1986).

6. William Liddle, "Islam, kultur dan demokrasi”, Jurnal Demokrasi dan HAM (May-August, 2000), 161.

7. Idem, "Indonesia in 2000: A Shaky Start of Democracy", Asian Survey 41 (January-February 2001), 182; Rizal Sukma, "Conflict Management in Post-Authoritarian Indonesia", in: Damien Kingsbury (ed.), Autonomy and Disintegration in Indonesia (London: RoutledgeCurzon, 2003), $12-23$.

8. Jamhari Makruf and Jajang Jahroni (eds), Gerakan salafi radikal di Indonesia (Jakarta: RajaGrafindo Persada, 2004).

9. Liddle, "Indonesia in 2000", 170.

10. Idem, "Islamic Turn in Indonesia: A Political Explanation", Journal of Asian Studies 55, no. 3 (August 1995), 613-34.

11. Azyumardi Azra, The Origins of Islamic Reformism in Southeast Asia: Networks of MalayIndonesian 'Ulamā' in the Seventeenth and Eighteenth Centuries (Crows Nest [NSW, Australia]: Asian Studies Association of Australia in association with Allen \& Unwin / Honolulu: University of Hawai'i Press, 2004), Chapter 2.

12. James L. Peacock, Muslim Puritans: Reformist Psychology in Southeast Asian Islam (Berkeley CA: University of California Press, 1978); Deliar Noer, Modern Islamic Movements: 1900-1942 (Ithaca NY: Cornell University, 1980), 29-52.

13. Samuel P. Huntington, The Clash of Civilizations? The Debate (New York: Council on Foreign Relations Press, 1993). 